\title{
A DETERMINIST'S PERSPECTIVE OF CRIMINAL RESPONSIBILITY
}

\author{
M. V. JULIAN*
}

The ageless conflict between the antithetical theories that free will on the one hand and determinism on the other is the key to understanding human behavior forms the substance of this philosophical analysis of criminal responsibility. The writer traces the historical development of criminology against the background of modern scientific thought to develop a model based on the principle that human behavior is the product of an interaction between personality and environment. Such a model combines elements of both predictability and uncertainty. His "prediction" test for criminality satisfies with simplicity the requirement that a scientific model be consistent with observation. Through its simplicity and credibility, the theory invites a fresh and challenging approach to the problem of determining criminal responsibility.

With Earth's first Clay They did the Last Man knead, And there of the Last Harvest sow'd the Seed:

And the first morning of Creation wrote

What the Last Dawn of Reckoning shall read.

\section{The Rubaiyat of Omar Khayyam}

\section{INTRODUCTION:}

In antique times before whimsy first congealed on damp cave walls, perhaps in some crepuscular evening, near the waning embers of a fire, men first speculated on the antecedents of behavior. To some it has always been plain that all man's thought and action is the culmination only of free choice. Others have seen the space for will ephemeral and narrow. And a few have felt in their core that will is a mirage . . . the subtile delusion of a mind coerced by surging currents and the careless flux of circumstance. From those ancient times to now no answer has been found. But men still speculate and fancy that an abstract truth abides.

Spinoza argued that free will cannot exist because the mind can will only what is determined by a cause "which is determined in its turn by another cause, and this by another, and so on to infinity". ${ }^{1}$ Pierre Laplace, more than a century later, extended the deterministic model of behavior to its ultimate conclusion: ${ }^{2}$

We ought then to regard the present state of the universe as the effect of its antecedent state and the cause of the state that is to follow. An intelligence, who for a given instant should be acquainted with all the forces by which Nature is animated and with the several positions of the entities composing it if further his intellect were vast enough to submit those data to analysis, would include in one and the same formula the movements of the largest bodies in the universe and those of the lightest atom. Nothing would be uncertain for him; the future as well as the past would be present to his eyes. The human mind in the perfection it has been able to give to astronomy affords a feeble outline of such an intelligence.

Mathematics and the natural sciences were founded on such modes of logic. Isaac Newton's awesome model of a universe of force and matter steeped its children in determinism. But furtive probes beyond the seething shells of atoms would reveal bewildering uncertainties, and paradox would burst the tidy comfort of his edifice.

- Assistant Professor, Faculty of Law, The University of Alberta.

1 Spinoza, Ethics, (1910), Translated by A. Boyle, at 74.

2 Pierre :Laplace as quoted by Sir Arthur Eddington, New Pathways in Science, (1959) at 74-75. 
Jeremy Bentham deliberately avoided articulation of this ancient riddle, ${ }^{3}$ but free will clearly played no part in his utilitarianism. Bentham based his thesis on the proposition that: "nature has placed mankind under the governance of two sovereign masters, pain and pleasure. It is for them alone to point out what we ought to do, as well as to determine what we shall do ... They govern us in all we do, in all we say, in all we think . . ." Like Spinoza, Bentham was committed to the belief that human will could be influenced only through the laws of strict causation. Though he was unaware of an unconscious genesis in human motives," criminology's debt to Bentham can be measured only by the sweeping power of his impact.

The first systematic attempt to utilize the causal philosophy of science to predict individual criminal behavior was made near the end of the 19th century by Cesare Lombroso. In doing so he founded the Positivist School of Criminology.

Lombroso's early research was concerned primarily with abortive attempts to discover biological determinants for criminal behavior. But in his later work Lombroso claimed that "every crime has its origin in a multiplicity of causes, often intertwined and confused . .."? He argued that crime, is a natural phenomenon, preceded in every case by an inexorable chain of causation, ${ }^{8}$ but never admitted the possibility that a criminal could be biologically "normal". Nevertheless, Cesare Lombroso's influence on the development of Criminology has been immense. It has been claimed that "the wide diffusion of the deterministic (in lieu of free will) approach to an understanding of crime and the most apropriate means for treatment should be credited to Lombroso."10

Comprehensive proposals for basing a criminal law system on the precepts of determinism were first articulated by Enrico Ferri. ${ }^{11}$ After a detailed philosophical discussion, he suggests that "we have seen how fully the theoretical and practical impossibility of resting man's responsibility for his crimes upon free choice, either absolute or relative, is proven". ${ }^{12}$ Ferri's articulation of the Positivist ideology had largely condensed from an abiding and mutually stimulating friendship between him and Lombroso; ${ }^{13}$ and although it was not totally accepted by all those who claimed the label "Positivist", none believed without reserve in the tenents of free will. ${ }^{14}$ Ferri's attempt to mold a system of criminal

3 David Baumgardt, Bentham and The Ethics of Today, (1966) at 88.

1 Jeremy Bentham, The Princples of Morals and Legislation, (1948) at 1.

5 Jeremy Bentham, Theory of Legislation, London, Translated from the French of Etienne Dumont by R. Hildreth, at 27.

- Hermann Mannheim, Pioneers in Criminology, London (1960) at 56. Reprinted from: Gilbert Geis, 46 J. Crim. L., C., \& P.S.

7 Cesare Lombroso, Crime Its Causes and Remedies, (1968) at 1, Translated from the French by Henry P. Horton.

8 Id., at 377-379.

See Leon Radzinowicz, Ideology and Crime, (1966) at 49-50.

10 Marvin Wolfgang, Pioneers in Criminology: Cesare Lombroso (1835-1909), (1961) 52 J. Crim. L., C., \& P.S. 361 at 390.

11 Enrico Ferri, Criminal Sociology, (1967). Translated by I. Kelly and John Lisle, at 288-307.

12 Id., at 308. Ferri's denial of free will was remarkably consistent throughout his entire political and academic career. For example, in a series of lectures given a generation after the original publication of his thesis he would insist: "how can you still believe in the existence of free will, when modern psychology armed with all the instruments of positive modern research, denies that there is any free will and demonstrates that every act of a human being is the result of an interaction between the personality and the environment of man? between the personalts and thect it phenom enon is the necessary schect of Criminology, Three Lectures Given at The University Ferri, The Positivist School of Criminology, Three Lectures Given at The

13 See Thorsten Sellin, Pioneers in Criminology-Enrico Ferri (1856-1929), (1958) 48 J. Crim. L., C., \& P.S., 481 at 486

14 Radzinowicz, supra, n. 9, at 51 . 
law from the denial of moral responsibility marked the crest of determinist influence on criminal law. The sciences of individual and group behavior have placed an ever deepening reliance on a deterministic model of human behavior, but criminal law remains confounded in the morass of free will.

The Positivists were concerned with the determinants of individual behavior. Other criminologists, among them William Adrian Bonger, studied the social forces affecting whole societies. ${ }^{15}$ The determinism of Bonger was more subtile than that of the Positivists, but it played a crucial role in the development of his thesis. Bonger argued that "the fluctuations of the mind of the person in whom the criminal idea is born may be compared with the oscillations of a balance; and it is upon sociology that must devolve the task of examining the forces which throw a weight on one side or the other. ${ }^{16}$... He who is born with weak social instincts runs more danger of becoming a criminal. But the certainty that he will become such does not exist-that depends upon the environment". 17

The passing of Ferri and Bonger tolled the eclipse of fresh enquiry by criminologists into these ancient questions. Only in the last decade has half a century of silence timorously been broken. Conceivably, the pervasive quiet flowed from a dimming prospect for success and the pragmatist's disdain for polemics. Or perhaps, as Radzinowicz suggests, "all that can be said on this subject was said long ago"."18

In the shimmering realm of atomic physics there has been no such silence. The all but universal determinism among physicists since the time of Newton ${ }^{19}$ was vaporized by the weird unorthodoxies of quantum mechanics. Neils Bohr's principle of complementarity altered our understanding of observation in every domain of experience ${ }^{20}$ by hypothesising the existence of certain paired quantities in nature so related that any attempt to measure one necessarily alters the system so that simultaneous determination of the other is impossible. Bohr's complementarity was a generalization of Werner Heisenberg's celebrated principle of indeterminancy which set limits on the accuraycy with which the related pairs momentum and position or energy and time could be determined..1 The implications of the uncertainty principle are truly awesome. The inevitable determinism of Newton's mechanics, suggests Heisenberg, "was perhaps enunciated most generally and most lucidly by Laplace when he spoke of a demon, who at a given time, by knowing the position and motion of every atom, would be capable of predicting the entire future of the world. But quantum mechanics has destroyed, perhaps

15 William Adrian Bonger, Criminality and Economic Conditions, (1967), Translated by Henry P. Horton, at 35: "I am of the opinion that individual differences are of great importance for one who is studying an individual by himself, but that they do not belong to the domain of the etiology of criminality."

16 Id., at $532-533$.

17 Id. at 535 . See -page 395 for an elaboration of this point. More specifically, Radzinowicz quotes Bonger as claiming in 1936 that one who ".. still adheres to the doctrine of free will, cannot be admitted to the criminologist fraternity." See Radzinowicz, supra, $\mathrm{n}$. 9 at 45 quoting from W. A. Bonger, An Introduction to Criminology (1936). supra, n. 9 at 45 quoting from W. A. Bonger, An Introduction to Criminology (1936). London (1960). reprints from J. Crim. L., C., \& P.S., at 358: ". . . for great men as well as for criminals he denles the existence of 'free will", and everything is explained by environmnetal circumstances."

18 Radzinowicz, supra, n. 9 at 108.

19 See Sir Arthur Eddington, New Pathways in Science, (1959) at 73.

20 Niels Bohr, Atomic Physics and Human Knowledge, (1958) at 99.

21 More accurately, Heisenberg's principle states that the product of the uncertainties must be at least as large as Planck's constant (i.e.: 6.625 $x$ 10-30 Joule-sec.). The insignificance of Heisenberg's Uncertainty Principle in the description of ordinary phenomena is readily apparent. See Widner and Sells, Elementary Modern Physics, (1960) at 142-157. 
forever, the dream that man will one day approach such a perfect intellect."22 Similarly, Neils Bohr submits that the principle of complementarity limits in no way the potential for experimentation ... it merely characterizes the answers receivable from such inquiry, ${ }^{23}$ and thereby "prevents comprehensive deterministic description".24

Not all physicists have accepted the indeterminancy of quantum mechanics as a final formulation. ${ }^{25}$ Hope is still cherished that a new model can be fashioned that will fill the void. "Some physicists, among them myself", Einstein observes, "cannot believe that we must abandon, actually and forever, the idea of direct representation of physical reality in space and time; or that we must accept the view that events in nature are analogous to a game of chance"." But it cannot be denied that the theorems of quantum physics outline the most comprehensive and successful model presently available.

Some have argued the existence of free will from the hypothesis that Heisenberg's uncertainty principle applies to the particles and waves of the brain. ${ }^{27}$ If anything is clear, it is that freedom cannot spring from uncertainty or seething chaos, and choice is meaningless without prediction. ${ }^{28}$ The determinism of Spinoza and Laplace has been tempered by the subtile pulse of chance, and a measure of randomness has seeped into perceptions of environment. But discovery of an unpredictable, chaotic element in nature creates no space for will. The antique paradox is no nearer to solution now than when it first swarmed amorphous along the boundary of some primordial imagination.

One is understandably moved to wonder where lies the profit in such inquiries, ... are they no more than metaphysical sophistries intrinsically without solution? Before examining this critical question we must diverge a moment.

The concept "model" has been employed here extensively to contemplate the mental image or the theory which represents an impinging of the unknowable external world upon our senses. A scientific model has no purpose but prediction, and pretends in no way to seek abstract validity. ${ }^{29}$ To describe a model as true or false is meaningless, for characterization can depend only on the degree of accuracy with which a particular model allows us to predict sensations from the external world. Free will and determinism are simply models we have built to help predict and control human behavior. Both are inefficient because they rely on incomplete data and imperfect calculations. The free will model is particularly suspect because it postulates a quantity which, by definition, precludes prediction. ${ }^{30}$ The model's success implies its failure, explaining, perhaps, its unique ability to encompass any hypo-

22 Werner Heisenberg, The Physicist's Conception of Nature, (1962) at 34. See also page 49

23 Niels Bohr, Essays (1958-1962) On Atomic Physics and Human Knowledge, (1963) at 4 .

34 Id., at 6.

25 See, for example, Albert Einsteln, Out of my Later Years, Thames and Hudson (1950) at 110: "at the present. we are quite without any deterministic theory directly describing the events themselves and in consonance with the facts."

26 Id.

27 See David L. Miller, Modern Science and Human Freedom, (1959) at 258-259, discussing the views of Arthur Compton.

28 Id. at 260 .

29 See Marshall Walker, The Nature of Scientific Thought, (1963), Capter I-VI

29 See Marshall Walker, The Nature of Scientific Thought, (1963), Capter I-VI American, November 1963 at 41 : "[i]t may be that in many areas men have a largely free and "undetermined" choice, but the scientiflc exploration of behavior canno begin unless that notion is excluded, just as in physics the notion of the "miraculous" is excluded." 
thesis and is contradiction. The basic logical flaws inherent in the very structure of the free will model have long been known, but there are better reasons for its re-examination as the foundation of our criminal law.

The entire history of criminal law reflects the fundamental dichotomies of human thought. "It is . . . natural to expect that the opposition which the terms determinism and indeterminism represent in the appraisal of human conduct, also applies, consciously or unconsciously, when one is faced with fundamental questions in criminal law." has been claimed, for instance, that from a practical point of view retribution presupposes indeterminism; ${ }^{32}$ and Radzinowicz argues simply that "the views we hold about why people commit crimes deeply influence our ways of dealing with them." ${ }^{33}$ The paradoxical impossibility of using aspects from both free will and determinism in the same model of human behavior has often been articulated. Max Born, for example, insists that: ${ }^{34}$

... only two possibilities seem to exist: either one must believe in determinism and regard free will as a subjective illusion, or one must become a mystic and regard the natural laws as a meaningless intellectual game. Metaphysicians of the old schools have proclaimed one or the other of these doctrines, but ordinary people have always accepted the dual nature of the world.

It is for these reasons that we have lingered here to glance at a model of behavior that has had so trivial an influence on our law. ${ }^{35}$

Our purpose is to shape alternatives for the model we have been long accustomed to. Neither free will nor absolute determination is its hallmark. The certainty of Newton must be tempered by the random chance of Heisenberg which allows a space for both prediction and uncertainty. It is with such a model of human behavior that fundamental precepts of our criminal law will be examined.

There's special providence in the fall of a Sparrow.

If it be now, 'tis not to come;

if it be not to come, it will

be now;

Hamlet, Act V, sc. ii

Part I, A Proposal:

We begin with the proposition that all of man's thoughts and behaviors are the product of a subtile interaction between environment, heredity and random chance. The role of probability is illusive. The part it plays in the journey of an atom is small; and few activities of living things imply its chaotic mark. But one thing is certain, there is no space for will. To the limit set by Heisenberg human behavior is totally predictable; beyond it there is only chaos. This, then, is the framework of our model.

Moral responsibility is a ludicrous concept, for a man can be no more responsible for his actions than a set of dice or a galaxy is. "Every-

31 Jos. Andenaes, Determination and Criminal Law, (1956) 47 J. Crim. L., C., \& P.S. 406 at 409.

82 Id.

33 Radzincowiz, supra, n. 9 at 53.

34 Grodzins and Rabinowitch, The Atomic Age, Basic Books, Inc. (1963), reprints from the Bulletin of the Atomic Scientists 1945-1963, Max Born, June 1957 at 596. Niels Bohr has characterized free will and determination as philosophical complements, suggesting that commitment to one concept necessarily precludes the other from rational consideration. See Walker, supra, n. 29 at 134 .

35 Jos. Andenaes, supra n. 31 at 41 . 
thing that men do or think concerns the satisfaction of the needs they feel or the escape from pain . . . man acts in accordance with . . . necessity, and would ... . be as little responsible as an inanimate object is for the movements which it makes."38

"Someone replies to us: 'But if you deny responsibility, what right have you to punish? You proclaim that a man is not answerable for his conduct yet you exact a penalty. How inconsistent and how harsh!' I shall never forget how a venerable thinker shook his head when he read these pages, and said to me: 'where will you arrive, with these premises? Must we let ourselves be pillaged and murdered by brigands upon the pretext that we cannot decide whether they know they are doing wrong?" "37 Lombroso did not seek far for his answer: "if crime is a necessary thing, so also is society's resistance to crime, and, consequently, the punishment of crime, which must be measured by the amount of apprehension with which it inspires the individual. ${ }^{38}$. . . It is just because the principle of punishment is based upon the necessity of defense that it is really not open to objection". ${ }^{30}$

Enrico Ferri echos these ideas in his introduction to the English translation of Criminal Sociology. Penal justice, he submits, should neither attempt to measure the moral fault of a delinquent nor try to mete out proportionate punishment, but can only be a tactical defense against crime. ${ }^{40} \mathrm{He}$ emphasizes that the defensive function must be totally independent of "moral culpability"."1

Given the model of human behavior we've adopted here, it is not easy to criticize the axioms of Ferri and Lombroso. But it is at this juncture that the deterministic model begins to find difficulty. Obviously, "in a particular situation where the crime is committed, it is the inevitable outcome of all the elements of the situation-as inevitable an outcome as any physical occurrence could possibly be". ${ }^{42}$ Is it illogical, then, to speak of a deterrent function in the law? And if so, how can an acceptable level of deterrence be maintained without the concept of responsibility?

Deterrence is, indeed, possible, even though for a particular person and a given set of external and internal elements, a particular crime is inevitable. The threatened imposition of a penal sanction simply works an alteration on the totality of environmental forces. A crime is still inevitable in that it is the product only of predetermined forces and random chance. But presumably some will be deterred who, under the pre-existing set of forces, would have acted differently. Sanctions must be visited upon those who cannot be deterred in order to retain their credibility to those on whom they work. ${ }^{43}$

As to your doctors and judges on uncontrollable impulse I think the short answer is that the law establishes certain minima of social conduct that a man must conform to at his peril. Of course as I said in my book it bears most hardly

86 Albert Einstein, Religion and Science, New York Times Mag. (Nov. 9, 1930), sec. 5.

87 Cesare Lombroso, supra, $n^{7} 7$ at 379. See also Enrico Ferri, supra, n. 11, addressing the same problem at 308 : "But then, if man commits misdeeds not by the free choice the same prob the fatal tyranny of his abnormal organism and his environment. the question arises, how can he be punished and made responsible for faults which the question not his?"

38 Cesare Lombroso, supra, n. 7 at 380.

30 Id., at 381 .

10 Enrico Ferri, supra, n. 11, introduction at page $x$, see also the text at 321

41 Id., at 321 .

18 Letter from Mr. Justice O. W. Holmes, Dec. 17, 1925. Holmes-Laski Letters, Edited by Mark DeWolf Howe, Harvard (1953) at 806. 
on those least prepared for it, but that is what it is for. I am entitrely impatient with broad distinctions. Otherwise we are lost in a maze of determinism. If I were having a philosophical talk with a man I was going to have hanged (or electrocuted) I should say, I don't doubt that your act was inevitable for you but to make it more avoidable by others we propose to sacrifice you to the common good. You may regard yourself as a soldier dying for your country if you like. But the law must keep its promises.

The impasse is reached when the attempt is made to totally abrogate responsibility as presently conceived. Can a model of criminal law be devised which will succeed in this, and still provide for acceptable levels of deterrence?

Ferri proposed a system that would require the commission of some "physical or muscular act" coupled with "the last phase (external or muscular) of a physio-psychological process psychologically free".44 Although quite consistent with his hypothesis, the model's complexity and difficulty of application is perhaps readily apparent.

The same problems have also been encountered, in more recent times, by those who have re-examined the uses of traditional concepts of responsibility in the criminal law. $H$. L. A. Hart, for example, criticizes the "extreme" approach that would effectively abolish the doctrine of mens rea. He favors one that would alter the concept only where it "concerns the legal responsibility of the mentally abnormal".45

Radzinowicz, too, finds insurmountable obstacles in the path of complete abolition of responsibility, and suggests that modification of the concept is possible, but no more. "Would it not suffice", he asks, after the fashion of Gabriel Tarde, "to hold an offender responsible if two conditions were satisfied: one that a certain degree of personal identity persisted in him at the time of the offense, the other that there was a certain degree of social similarity recognized between him and his victim, him and his accuser. Instead of being linked with liberty responsibility should thus be linked with identity."46 Admittedly, this approach avoids the determinism-free will dilemma, ${ }^{47}$ but would it not rely on concepts at least as nebulous and indefinable? Such a system would be little less complex and unwieldy in application than what we have today.

Barbara Wootton has boldly proposed the simple abolition of responsibility. She suggests that such an approach need not be grounded in determinism to allow full scope for utilization of the scientific method in criminal law. ${ }^{18}$ But our observations here will make it plain that something must be found to fill the void left by responsibility's departure.

Our axiom is that men do what they must ... . as inexorably as a bit of flotsam in a torrent. The forces of heredity, environment and chance demand obedience. And retribution is as bizarre a concept as the mind can fancy; but the threat of pain in order to deter is essential, for human behavior can be directed by the imposition of a force even as a speck of matter can. The subtile fluxing of the mind is only more complex.

The paradox is this: excusing crimes that are inevitable excuses all, for nothing done could have been avoided. The threat of pain is gone, and

44 Enrico Ferri, supra, n. 11 at 340.

45 H. L. A. Hart, Punishment and Responsibility, (1968) at 195-196, 205.

16 Radzinowicz, supra, n. 9 at 110. See also Mannheim. Pioneers in Criminology, London (1960), reprinted from J. Crim. L., C., \& P.S., Gabriel Tarde, Margaret S. Wilson 7 Mannhelm, Pioneers in Criminology, supra, n. 6 at 235.

48 Barbara Wootton, Diminished Responsibility: A Layman's View, (1960) 76 L.Q. Rev. 224 at 239. 
all restraining forces of most potency are lost. A point of compromise is essential. We must accept the inevitability of human deeds, but recognize the need to alter the totality of forces permeating our environment ... determine a technique to apply the minimum of pain that will allow for maintenance of acceptable levels of deterrence. Two distinct situations must be considered: first, protection against those who threaten us with lingering danger, and second, the need to visit sanctions on those who are no future threat so others might be deterred. These are the irreducible minima of social defense.

When a person is detained because he is a continuing danger to society, that should be the charge; and the state ought to prove the existence of a reasonable probability that the accused will take part in certain activity in the future. Safeguards must, of course, be developed to minimize the number and effect of errors in the system. Perhaps it should be doctrine that first it be shown that the accused committed certain unlawful acts, and maximum terms of treatment served only where rehabilitation fails, could provide additional defense against harshness and mistake.

It is in the second, and more subtile, branch of criminal law, where sanction is used to deter others, that fundamental change is contemplated. Again, the state should prove initially the performance by the accused of an unlawful act. But mere proof of that is not enough. The following test should be applied:

Using the best mehods available, would it have been predictable to a high degree of probability that the accused would not, absent reliance on this test, have been deterred by the threat of then existing criminal sanctions?"

Clearly, the particular accused was not deterred, and hence, under the totality of circumstances, could not have been deterred. The crime was inevitable for him, but the test does not adopt that perspective. If it did, no one would be subject to sanctions and the criminal law would have no effect on those who are deterrable.

When all relevant facts describing the myriad of forces acting on the accused are compiled, we ask: could it have been predicted that he would do the act? If the answer is "yes", and there is no probable future threat, the accused will be freed. The test moves as far as possible toward minimization of the use of sanctions. The next step must clearly be to ask if the accused could have been deterred.

Next, we must inquire if such an approach would significantly decrease the level of deterrence. The only way criminal sanctions can affect behavior is through a conscious or unconscious weighing by a potential actor of the probability and intensity of pain resulting from that behavior against the probability and intensity of pleasure to be derived from it. ${ }^{49}$ I submit that few, if any, who are deterred by an approach based on "free will" would fail to be deterred by the "prediction" test. In both systems the awesome threat of sanctions permeates all human activity. The general foreboding, the deep-rooted, semi-conscious premonitions of danger when one skirts near the fringes of criminal law would still be evidenced. And few who concretely reason out the probabilities would believe that their own behavior could be found

19 "A second aspect of the brain is its ability to compute the probability of survival resulting from several possible modes of action, pick the maximum, and direct the motor centers accordingly. The process goes on automatically and has recelved the ironic name 'free cholce'." Walker, supra, n. 29 at 100. 
highly predictable. The levels of deterrence would not appreciably be altered by an approach based only on prediction.

Two contrasting values have been met: minimization of the totality of pain imposed by society along with the maintenance of acceptable levels of deterrence.

It is proposed, then, that every criminal trial consist of three parts. First, it must be determined if the accused committed an unlawful act; second, the possibility of continuing danger to society need be considered. And finally, we must ask whether it could have been predicted to a high degree of probability that the actor would not have been deterred. In each part, all the procedural and substantive safeguards feasible at that particular time in the society's development should, perhaps, be afforded. And a plea of "not guilty by reason of predictability' might be specially required before it became an issue. Possibly, the burden of going forward with evidence could best be placed on the defendant, but such details must be formed in practice.

The following table outlines the direction a criminal trial would take under such a model.

(1) Was the behavior of

the accused of such

a nature that he

has been properly

brought within the

ambit of the crim-

inal law?*
(2) Does the accused

present a continuing

: threat to society? :

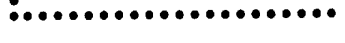

SET OF ALL POSSIBLE ANSWERS

(3) Using the best methods available, would it have been predictable to a high degree of probability that the accused would not, absent reliance on this test, have been deterred by the threat of then existing criminal sanctions?
NO No further inquiry is necessary, for the accused could not be found "responsible" irrespective of the answers to questions (2) and (3).

YES

(i) $\mathrm{NO}$

(ii) NO

(iv) YES

:

(iii) YES

(i) The accused would be visited with sanctions for the sole purpose of deterring others.

(ii) The accused would be found "not responsible" and immediately released. This result is the only one that is significantly different from the present modes of criminal law administration.

(iii) The accused would, in this situation, be subjected to criminal sanctions for the purpose of deterring others. He would also be incarcerated for treatment and to protect society from his future behavior.

(iv) In this case the accused would be sentenced (or otherwise dealt with) for an indefinite period for the sole purpose of rehabilitation. A maximum period should, perhaps, be stipulated as a partial safeguard against error in the fact finding process.

* An essentially equivalent formulation of this question might be: "did the accused fulfill all the physical elements of the crime," or "did the accused commit all the acts, omissions, attempts and other physicai requirements which constitute the definitions of the offense?" 
It must be emphasized at this point that the predictability test proposed here is meant to supplant all other mental tests of culpability ... a and sweep still further. Mens rea will, of course, no longer be a part of criminal liability. The doctrines of self defense, justification, necessity, insanity and a host of other concepts would no longer play a central role in the determination of "guilt". Where these doctrines would be applicable under present law, the "predictability" model would apply for different reasons. That such a surprising similarity can be derived from two fundamentally dichotomous perspectives, implies that the differences are more abstract than functional. Nevertheless, one axiom that has proved invaluable from the beginning of human experience is that the simplest workable model is best. But let us look more closely at the ramifications of this idea.

No single thing abides; but all things flow

Fragment to fragment clings-the things thus grow

Until we know and name them. By degrees

They melt, and are no more the things we know.

LUCRETIUS

Part II, A Justification:

H. L. A. Hart is vehemently opposed to Barbara Wootton's suggestion that the concept of responsibility should be allowed to wither away. ${ }^{30} \mathrm{He}$ sees a vast increase in the occasions for official interference with privacy as a necessary consequence of the abolition of mens rea. Without mens rea, Hart argues, “ . . . every blow even if it was apparent to a policeman that it was purely accidental or merely careless . . . would be a matter for investigation under the new scheme ...".1 But this is simply not true. It is certainly predictable, indeed rather obvious, that an accidental or careless blow cannot be deterred by the threat of sanctions. Application of the "predictability of deterrence" test produces the same result as the mens rea requirement. The remote possibility of a court finding it unpredictable that such a blow could not be deterred by the threat of criminal sanctions is obviously no greater than the chance of a court finding mens rea. Indeed, it is suggested that it might be considerably easier to apply a "prediction" test than to journey into the realm of the unknown and unknowable. Hart maintains further that in his hypothetical situation there would be a need for investigation to determine if treatment were necessary ... thus increasing the incidence of harassment by officials. Again, the argument is unconvincing. It is at least as certain that the perpetrator of an accidental blow is not a continuing threat to society as it is that he is not a psychopath running amok, a dangerous vagrant, or even, perhaps, a habitual criminal. The abolition of responsibility and its replacement by a model based only on prediction would give no impetus to the steady draining away of our privacy. One suspects that some technique could be found in any system to justify officialdom's desire to meddle with the privacy of an individual.

Hart's next objection is divided into two parts. He claims that it is clearly immoral to imprison a person to deter others unless he could "help" doing what he did. The individual, Hart suggests, has a right

50 H. L. A. Hart, supra, n. 45 at 206.

01 Id. 
not to be used in this way. ${ }^{52}$ Such an argument is blatant sophistry. It depends on the proposition that there is some abstract validity, some intrinsic truth, in either the deterministic or free will model of behavior. But both are neither correct nor incorrect ... only particular perspectives that aid us to explain behavior. The rationalization that an accused could 'help himself', in order to justify the necessary imposition of sanctions, is hardly convincing to one who has accepted a deterministic model. Hart may soothe his conscience with such a fiction, but some, unfortunately, are left without that comfort. And one wonders if the pain of sanctions is borne more easily by those who fancy that they could have "helped themselves."

The second part of the objection visualizes abolition of a deterrent function in the criminal law. Hart postulates a need for both deterrence and a hostile obloquy for those subjected to the criminal sanctions. He wonders, if a criminal cannot help himself, how can he be the subject of society's odium, and will not the law have, then, lost important parts of its potency? ? $^{33}$ What Hart really seems to fear is an upsurge of tolerance and understanding. Admittedly, the realization that people do what they must makes hatred and disgust rather difficult: "it is a psychological paradox that the belief in universal determinism liberates the mind from hatred as well as from praise and blame which a belief in human freedom would foster." 54 If the elimination of responsibility will do as much for us as Hart fears, perhaps a trivial decrease in our power to deter is a small price to pay.

Finally, Hart argues that a disappearance of responsibility necessarily implies abolition of crimes based on mental elements . . . such as attempt. ${ }^{.5}$ Elimination of responsibility does not imply a focus exclusively on physical acts. Because the law will no longer ask "could he have done otherwise", does not mean it cannot ask "was it done to effect a particular purpose" or "was it accidental or mistaken". Indeed, such questions must be asked, for they bear directly on the issue of prediction. It is in no way illogical to ask about motive and purpose while eschewing inquiry into responsibility. The formulation articulated here provides a probability continuum along which such concepts as "willfulness", "maliciously", "purposive" and "negligent" can be placed. The abolition of responsibility leaves one area of criminal law as confused as it is found, but that implies nothing of the proposal's merit elsewhere.

Hart's objections are, however, quite applicable where he intended them. The idea propounded by Barbara Wootton that responsibility should be allowed to wither away is incomplete. Without something to replace it, the cricitisms expressed by Hart are valid. We have seen that an extremely simple and most practical replacement is quite feasible.

Leon Radzinowicz equates the abolition of responsibility with a total mutation in the purposes of criminal law. He conceives of the new formulation as asking not whether an offender ought to be punished but

52 Id., at 207.

53 Id., at 209.

54 David Bidney, The Psychology and Ethics of Spinoza, (1962). The statement was made in a discussion of the determinism of Spinoza, Abraham Lincoln and Albert

55 Einstein, at 300 . Hart, supra, n. 45 at 209 :

58 Radzinowicz, supra, n. 9 at 109 , addressing himself to Barbara Wootton's proposals. 
whether he would be likely to benefit from punishment. ${ }^{56}$ The system envisaged by Lady Wootton makes this implication ${ }^{57}$. . . the one articulated here does not. But the objections of Radzinowicz go deeper, and he wonders how, without responsibility, society could decide whom to treat or punish. The objection is inapplicable to a model based upon prediction. Clearly, one who is no future threat need not be treated, but may be subjected to sanctions for the deterrence of others; and one who predictably could not have been deterred but who presents continuing danger needs treatment. Rare situations that fall into both categories can be dealt with accordingly. No implication is intended that determination of who fits within each category will be simple. All that is suggested is that inquiry will be directed to the fundamental questions; and no longer will they be answered indirectly through a shroud of responsibility, insanity and mens rea.

Radzinowicz argues further that a denial of responsibility would increase anomie and thus nourish the roots of modern crime. His premises imply the conclusion, but not everyone is ready to assume that responsibility is the antithesis of anomie. On the one hand it can mean a moral nexus between the will and an act. That concept has been rejected here, and its relation to anomie is far from clear. ${ }^{58}$ On the other hand, responsibility can refer to a susceptibility to the natural sanctions of environment. A moth that moves too near a flame, a toad that wanders past a serpents lair, and the brigand who pillages and murders are all responsible, for all must bear the consequences. For most, this much responsibility sufficies. The inherent biological thirst to maximize the probability of survival, and the craving to fulfill other deeply felt desires are far more potent than the presumed need to be morally responsible.

We have seen how criminal law can be condensed into an elegant and simple form ... how a myriad of unworkable and disparate concepts can be gathered in a single formulation. The major question still remaining is its practicality in application. Little need be said of that. The sophistries imposed on the courts, psychiatry and medicine by what we have today are obvous. All must address themselves to questions that are unanswerable. A distinction between what was not resisted and what could not be resisted is logically impossible. ${ }^{59}$ The disdain among psychiatrists for the criminal law's penchant for meaningless questions is notorious. It has been argued that psychiatry, in its fervor to find a workable compromise with the law, has adopted concepts

57 Wootton, Diminished Responsibility: A Layman's View, (1960) 76 L.Q. Rev. 244 at 239: "forget responsibility and we can ask not whether an offender ought to be punished, but whether he is likely to benefit from punishment." See also Wootton, Social Science and Social Pathology, (1959) at 253-254 Perhaps a more practical and better articulated model in the same theoretical plane is the one illustrated by Sachar: "la more far-reaching collaboration would require a the one linustrated by Sachar: decision by judges and legislators effective in upholding and solemnizing the moral code, and would be consonant with the moral temper of the age, as the imperative "you must be morally condemned and punished." Edward Sachar, supra, n. 30 at 42.

58 Edward Sachar, supra, n. 30 at 41 quotes Melita Schmideberg of the Association for the Psychiatric Treatment of Offenders as saying that if you condemn the offender, you give up all hope of treating him, but if you condone his offense, you give up all hope of changing him.

59 "The step between 'he did not resist the impulse' and 'he could not resist the impulse' . . is one which is incapable of scientific proof." $R$. v. Byrne [1960] 3 A]l E.R. 1 at $\dot{5}$.

60 Zilboorg, Misconceptions of Legal Insanity, (1939) 9 A. J. of Orthopsychiatry 540 at 550. The author refers to the doctrine of free will as a "basic human megalomanic superstition", see page $\mathbf{5 4 9}$. 
"such as legal insanity and responsibility which are scientifically untenable"." The solution recommended by Zilboorg is that: ${ }^{11}$

Official psychiatry would perform the greatest service to law and medicine if it would decree that any expert psychiatric testimony admitting the existence of legal insanity and accepting the concept of legal responsibility is not in accordance with the basic tradition of the profession and automatically and officially disqualifies the expert in the eyes of the profession itself.

We could then face the court with a clear scientific conscience and feel professionally unassailable; we could tell the Court what we know; we would not join hands with the law in talking a language we at best do not understand and at worst consider incongruous.

Barbara Wootton is of the same opinion. She maintains that the withering away of responsibility is the only way all the contradictions can be resolved and all the unanswerable questions avoided. "Forget responsibility", she argues, "and psychiatrists need no longer masquerade as moralists, but can return to their proper role of applied scientists analyzing causes, predicting developments and indicating methods of control." 62

It is submitted that a test for criminality based on prediction of deterability is uniquely susceptible to application. Some form of prediction is the ultimate objective of all scientific endeavor; and in the end it is all that our abstrat tools are capable of. Perhaps the model suggested here, aside from its wide simplifications, would allow a modicum of communication between law and the social sciences.

These observations are not intended to imply that the question "could you have predicted to a high degree of probability that the accused would not have been deterred by the threat of penal sanctions" is a simple one to answer. Its virtue is that it directs scrutiny to the ultimate issues. Only in this way can we avoid the obliqueness of an approach which shrouds essentially the same queries in superstition.

With a model based on prediction, the answers may be equally hidden, but the questions are brazenly plain. Something must be given to simplicity. Above all else, the model proposed here has that virtue. For in its single formulation it encompasses a myriad of diverse and conflicting doctrines. It is an approach that would, perhaps, allow those less steeped than we in the ancient traditions to find comfort in understanding the law.

\section{Conclusion:}

The vast mysteries unfolded by delusions of a human will must some day seep away forgotten. To know how men are used by circumstances leaves no space for odium . . . but only tolerance, for we are all adrift together in the flux and torrent, even as the things around us are. Coercion implies no more than the boundaries of our craving for survival. Alternatives suggested here are those which seem to melt most closely with such a model of reality. 